\section{International Scientific Journal Theoretical \& Applied Science}

p-ISSN: 2308-4944 (print) $\quad$ e-ISSN: 2409-0085 (online)

Year: $2016 \quad$ Issue: 6 Volume: 38

Published: $30.06 .2016 \quad \underline{\text { http://T-Science.org }}$

SECTION 8. Architecture and construction.
Andrei Mastislavovich Korneev

Doctor of Technical Sciences, Professor, director of the institute of Lipetsk State Technical University, Russia, Lipetsk

Olga Petrovna Buzina

Candidate of Technical Sciences, Associate Professor, head of the department of Lipetsk State Technical University, Russia, Lipetsk

Andrei Vladimirovich Sukhanov postgraduate student, assistant of Lipetsk State Technical University, Russia, Lipetsk

Ilya Andreevich Shipulin postgraduate student, assistant of Lipetsk State Technical University, Russia, Lipetsk shipulin-ilya@yandex.ru

Nikita Andreevich Shipulin student of Lipetsk State Technical University, Russia, Lipetsk

\title{
MATHEMATICAL MODELING OF STRESS-STRAIN STATE OF COMPOSITES REINFORCED WITH DISCRETE FIBERS IN TENSION AND COMPRESSION, TAKING INTO ACCOUNT PHYSICAL NONLINEARITY
} \begin{abstract}
constructed using a modified formula and experimental data. diagram.

Language: English \& Applied Science, 06 (38): 124-130.

Expanding the use of reinforced structures of concretes which include the secondary wastes of different industries and local aggregates, promotes economical consumption of material and energy resources, reduce the cost and time consuming processes. These concretes, in particular, to fine slag concrete based on dropout from the crushing of the cast slag crushed stone (CSC). One of the ways to improve the quality of the concrete is the introduction of the slag mixture of steel fibers having high strength characteristics and increased tensile modulus.
\end{abstract}

Abstract: The article presents the study results of the stress-strain state of the steel fiber reinforced slag concrete elements. In order to determine the physical and mechanical characteristics of the fiber-reinforced concrete experiments carried out, the analysis of which yielded mathematical relationships to describe the stressstrain model in tension and compression for designs of such cementitious composites. To describe the stress-strain state modified depending offered N. I. Karpenko and C. Sujivorakul. The mathematical models used piecewise linear displacement diagrams fibers in concrete. Authors analyzed the convergence of the theoretical curves

Key words: steel fiber, stress-strain model, tensile behavior, compressive behavior, stress-deformation

Citation: Korneev AM, Buzina OP, Sukhanov AV, Shipulin IA, Shipulin NA (2016) MATHEMATICAL MODELING OF STRESS-STRAIN STATE OF COMPOSITES REINFORCED WITH DISCRETE FIBERS IN TENSION AND COMPRESSION, TAKING INTO ACCOUNT PHYSICAL NONLINEARITY. ISJ Theoretical

Soi: http://s-o-i.org/1.1/TAS-06-38-26 Doi: crossef http://dx.doi.org/10.15863/TAS.2016.06.38.26

It is known that the introduction of concrete reinforcement allows to obtain the dispersed composite having a tensile strength several times higher than for concrete matrix. Increasing the strength properties of steel fiber reinforced slag concrete (SFRSC) allow to eliminate the reinforcing bars in some designs.

Importantly, increase the level of automation of calculations structural elements makes higher demands on the information content of the research results of the actual work, which is particularly important for creating predictive algorithms using diagram methods. A large part of building 
construction elements based on such characteristics of the material, as the prism compression strength of concrete $R_{b}$, cube compression strength $R_{m}$ or durability of concrete under axial tension $R_{b t}$. A set of data for SFRSC-structures is not sufficient, because in addition to the strength properties of a significant role in the calculation here is also included a deformability (initial modulus of elasticity of the slag concrete (SC) in tension $E_{b 0}$ and modulus of elasticity of the SFRSC $E_{f b o}$, limit deformation in tension of the SC $\varepsilon_{b t R}$ and for SFRSC ${ }_{f b t R}$, limit deformation in compression of the $\mathrm{SC} \varepsilon_{b R}$ and for SFRSC $\left.\varepsilon_{f b R}\right)$.

The aim of this study is to provide a computational formula that will determine the deformation characteristics SFRSC taking into account the concrete age. On the basis of experimental data to construct incremental algorithm for calculating the structural elements under axial tension and compression loads.

The main findings deformability properties of fine-grained concrete are given in [1].

Tests were conducted with the specimens which include fine-grained slag produced of "NLMK". It is a waste of crushing of cast slag crushed stone gravel fractions $0-5 \mathrm{~mm}$ and a bulk density 1085-1135 $\mathrm{kg} / \mathrm{m}^{3}$. For the production of the specimens was used the composition, presented in table 1 .

Table 1

Composition of experimental specimens.

\begin{tabular}{|c|c|}
\hline Composite & Characteristic \\
\hline binder & cement brand PC-500 D0 (Lipetsk) \\
plasticizer & "Relamiks" (10\% solute) \\
particulate reinforcement & Fiber "Dramix" Belgian firm "Bekaert" - chopped steel wire $0.8 \mathrm{~mm}$ in diameter and \\
& $60 \mathrm{~mm}$ in length $\left(R_{f}=1100 \mathrm{MPa}, E_{f}=1,95 \cdot 10^{5} \mathrm{MPa}, d_{f}=0,8 \mathrm{~mm}, l_{f}=60 \mathrm{~mm}\right)$ \\
\hline
\end{tabular}

Test specimens in tension was conducted on a special experimental device [2]. Compression and tensile tests were occurred using $100 \mathrm{kN}$ press and universal tensile testing machine with maximal load $20 \mathrm{kN}$ respectively. In the study in tension and compression SFRSC-specimens used concrete matrix classes B5, B7.5, B10, B15, B20, B25, B27.5.
In studies of SFRSC-specimens on tensile varied volumetric content of fiber reinforcement $\mu_{f v}$ $(\%): 0,0.125,0.25,0.375,0.5,0.75,1.3$, and concrete age $t$ (days): $3,7,14,21,28,56,112,224$, 448. The sketches of specimens shown in Fig. 1. The distance between the fiber-in transverse section of the specimens were 5 and $10 \mathrm{~mm}$.

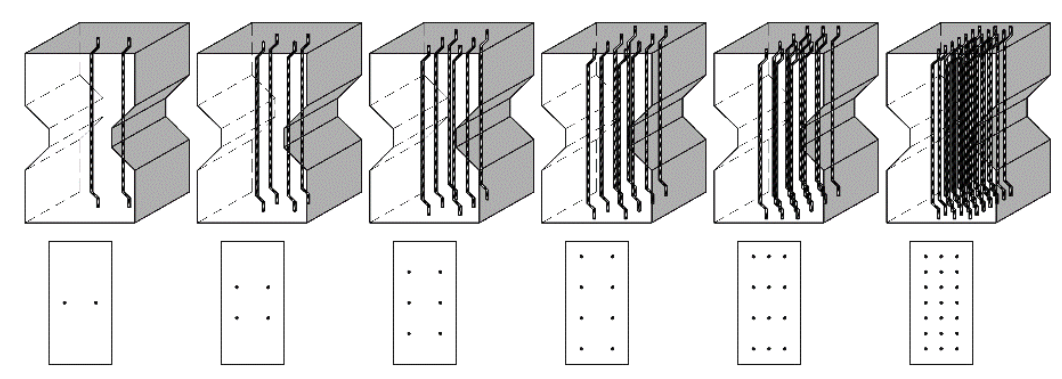

Figure 1 - Sketches of specimens for tensile test.

Durability of SFRSC in axial compression was determined on specimens in the form of cube with sides of $60 \mathrm{~mm}$. Variability of fiber reinforcement volumetric content in SFRSC-specimens $\mu_{f v}(\%)$ : 0 , $0.125,0.25,0.375,0.5,0.75,1.3$, and concrete age $t$ (days): 3, 7, 14, 21, 28, 56, 112, 224, 448; coefficient reflecting fibers work in a section perpendicular to the direction of the external compressive load $k_{n}$ : $0,247,1,00$. Sketches of test samples are shown in Fig. 2 a, b. 


\begin{tabular}{|c|c|c|c|c|c|c|}
\hline Impact Factor: & $\begin{array}{l}\text { ISRA (India) } \\
\text { ISI (Dubai, UAE } \\
\text { GIF (Australia) } \\
\text { JIF }\end{array}$ & $\begin{array}{l}=1.344 \\
=0.829 \\
=0.564 \\
=1.500\end{array}$ & $\begin{array}{l}\text { SIS (USA) } \\
\text { PUHЦ (Russia) } \\
\text { ESJI (KZ) } \\
\text { SJIF (Morocco) }\end{array}$ & $\begin{array}{l}=0.912 \\
=0.234 \\
=1.042 \\
=2.031\end{array}$ & $\begin{array}{l}\text { ICV (Poland) } \\
\text { PIF (India) } \\
\text { IBI (India) }\end{array}$ & $\begin{array}{l}=6.630 \\
=1.940 \\
=4.260\end{array}$ \\
\hline
\end{tabular}

a)
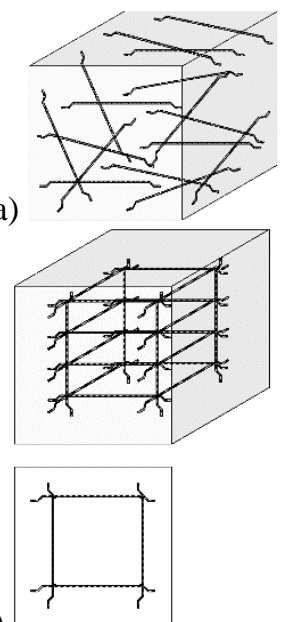

b)

Figure 2 - Sketches of specimens for compression test: a) $k_{n}=0,247$, b) $k_{n}=1$
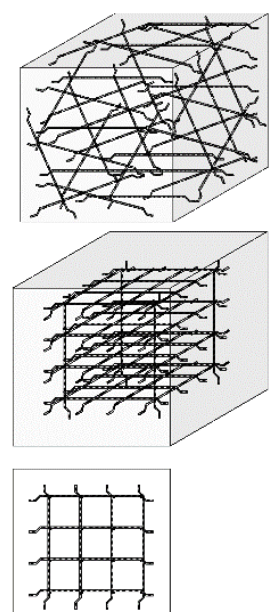
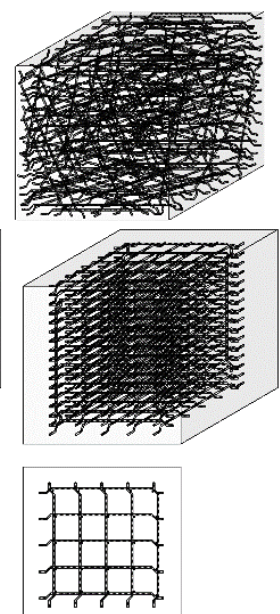
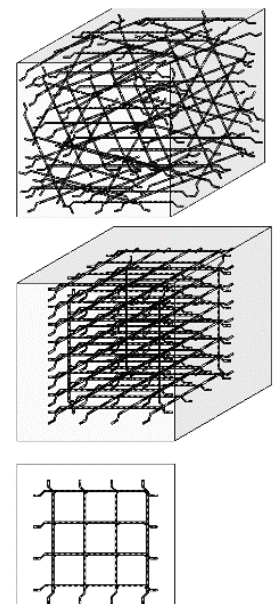

class B20) and Fig. 3 b (aged for 28 days concrete matrix class B20).

b)

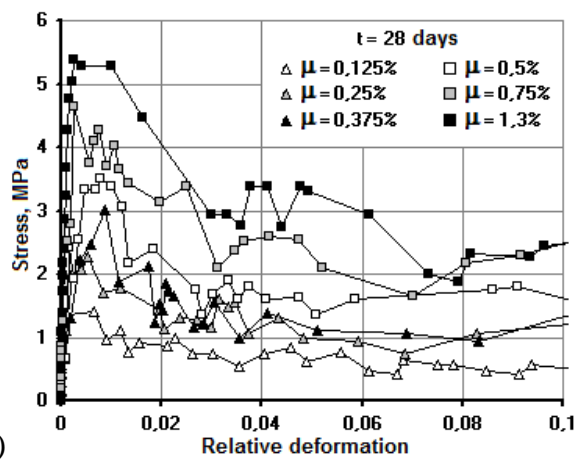

Figure 3 - Experimental " $\sigma-\varepsilon$ " diagrams obtained in an axial tensile test of SFRSC-specimens.

Deformation of SFRC is a complex process, the study of deformation tensile properties of SFRC revealed that it is characterized by the following work stages:

- practically linear section of the diagram " $\sigma-\varepsilon "$ corresponding to the elastic material;

- curved " $\sigma-\varepsilon$ " section of the diagram, starting with the crack corresponding to the pseudo-plastic material work.

Various researchers $[3,4,5]$, despite receiving comparable data, provide a variety of interpretations of the results. Thus, at the present time authors deduce various estimates moment of cracking due to differences in the test methods, experimental specimens and used equipment.

Tensile diagram " $\sigma-\varepsilon$ " for SFRSC can be represented as schematic form shown in Fig. 4 a. This diagram conditionally divided into two portions and described using seven characteristic points. The bright area of the diagram is the area where there is collaboration fiber and concrete work (occurs addition of tension diagrams concrete and fiber), the dark area of diagram describes comprehensive work of the fibers in pull-out of the slag concrete-matrix. 


\begin{tabular}{|c|c|c|c|c|c|c|}
\hline Impact Factor: & $\begin{array}{l}\text { ISRA (India) } \\
\text { ISI (Dubai, UAE } \\
\text { GIF (Australia) } \\
\text { JIF }\end{array}$ & $\begin{array}{l}=1.344 \\
=0.829 \\
=0.564 \\
=1.500\end{array}$ & $\begin{array}{l}\text { SIS (USA) } \\
\text { PИНЦ (Russia) } \\
\text { ESJI (KZ) } \\
\text { SJIF (Morocco) }\end{array}$ & $\begin{array}{l}=0.912 \\
=0.234 \\
=1.042 \\
=2.031\end{array}$ & $\begin{array}{l}\text { ICV (Poland) } \\
\text { PIF (India) } \\
\text { IBI (India) }\end{array}$ & $\begin{array}{l}=6.630 \\
=1.940 \\
=4.260\end{array}$ \\
\hline
\end{tabular}

a)

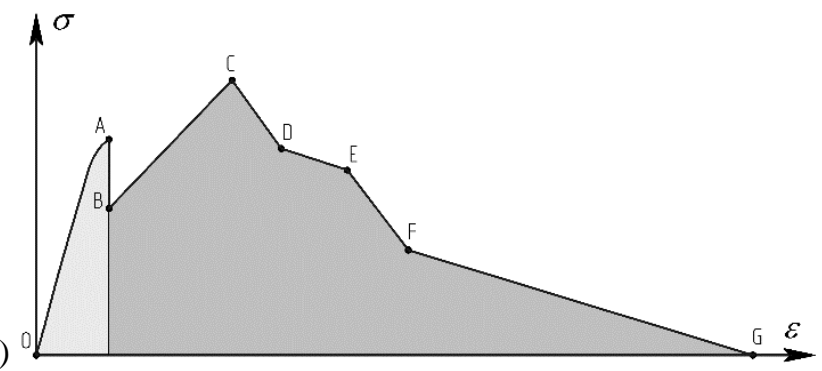

b)

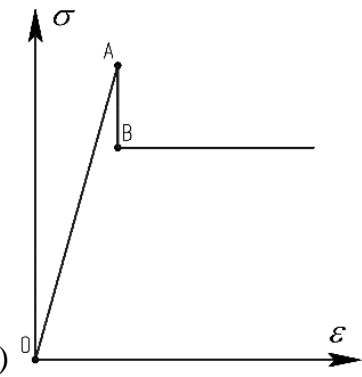

Figure 4 - Schematic forms tensile diagram for SFRC and its characteristic points.

In this case, the stress in section of concrete specimens at the site when the relative deformation of the sample does not exceed the limit values of

$$
N_{f b t}=N_{b t}+N_{f t}
$$

where $N_{f b t}, N_{b t}, N_{f t}$ is loads generated by tensile in SFRSC specimens, in concrete and in the fiber respectively. Expressing load through the voltage

$$
\begin{gathered}
N_{b t}=\sigma_{b t} A_{b}=\varepsilon_{f b t} E_{b, r e d} A_{b}, \\
N_{f}=\sigma_{f} A_{f}=\varepsilon_{f b t} E_{f, r e d} A_{f}, \\
N_{f b t}=\varepsilon_{f b t}\left(E_{b, r e d} A_{b}+E_{f, r e d} A_{f}\right), \\
\sigma_{f b t}=\frac{\varepsilon_{f b t}\left(E_{b, r e d} A_{b}+E_{f, r e d} A_{f}\right) .}{A_{b}+A_{f}}
\end{gathered}
$$

There $\sigma_{b t}, \sigma_{f}, \sigma_{f b t}$ is stress values in slag concrete, fiber and SFRSC respectively; $A_{b}, A_{f}$ is sectional area slag concrete and fiber; $E_{b, r e d}, E_{f, r e d}$ is the module of elasticity of slag concrete and fiber; $\varepsilon_{f b t}$ is relative deformation of SFRSC specimen.

$$
\varepsilon_{f b t R}=0,24 \cdot \sqrt[3]{R_{b t}(t)}\left(1+8 k_{o r}^{2} \mu_{f v}\right) \cdot 10^{-3},
$$

where $R_{b t}(t)$ is the tensile strength of concrete at the age $t, \mu_{f v}$ is volumetric content of fiber reinforcement.

Further, when the relative deformation of the sample exceeded the limit value relative deformations slag concrete-matrix $\left(\varepsilon_{f b t}>\varepsilon_{f b t R}\right)$, the

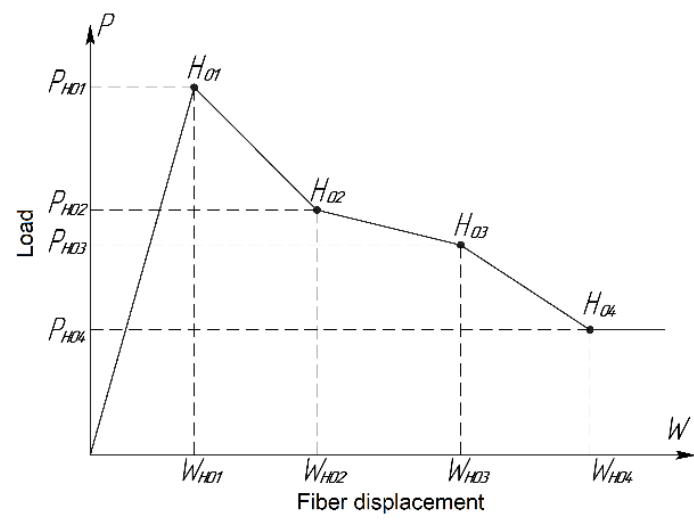

Figure 5 - The "load-displacement" single fiber pull-out piecewise linear diagram

In [6] presented the results and conclusions of the mathematical relationships for the coordinate reference points piecewise linear pull-out diagram diagram is described by adding the single fiber pullout diagrams.

The "load-displacement" curve for the loaded end of the fiber with a single limb at the end can also be represented as a piecewise linear diagram (Fig. 5). equation: concrete-matrix $\varepsilon_{f b t R}$ will also depend on the percentage of volume of reinforcement: 


\begin{tabular}{|c|c|c|c|c|c|c|}
\hline Impact Factor: & $\begin{array}{l}\text { ISRA (India) } \\
\text { ISI (Dubai, UAE } \\
\text { GIF (Australia) } \\
\text { JIF }\end{array}$ & $\begin{array}{l}=1.344 \\
=0.829 \\
=0.564 \\
=1.500\end{array}$ & $\begin{array}{l}\text { SIS (USA) } \\
\text { PИНЦ (Russia) } \\
\text { ESJI (KZ) } \\
\text { SJIF (Morocco) }\end{array}$ & $\begin{array}{l}=0.912 \\
=0.234 \\
=1.042 \\
=2.031\end{array}$ & $\begin{array}{l}\text { ICV (Poland) } \\
\text { PIF (India) } \\
\text { IBI (India) }\end{array}$ & $\begin{array}{l}=6.630 \\
=1.940 \\
=4.260\end{array}$ \\
\hline
\end{tabular}

Table 2

\begin{tabular}{|l|c|}
\hline - point $H_{01}:$ & $W_{H 01}=1-0,02 R_{b}(t), P_{H 01}=\left(355+11 R_{b}(t)\right)\left(0,55+0,015 l_{f, a n}\right) ;$ \\
- point $H_{02}:$ & $W_{H 02}=3 W_{H 01}, P_{H 02}=0,7 P_{H 01} ;$ \\
- point $H_{03}:$ & $W_{H 03}=6 W_{H 01}, P_{H 03}=0,6 P_{H 01} ;$ \\
- point $H_{04}:$ & $W_{H 04}=8 W_{H 01}, P_{H 04}=0,4 P_{H 01}$ \\
\hline
\end{tabular}

There $l_{f, a n}$ is embedding fiber length ( $\left.\mathrm{mm}\right), R_{b}(t)$ is slag concrete compressive strength at age $t(\mathrm{MPa})$, $W_{H O i}$ is abscissas points (displacment of fiber, $\mathrm{mm}$ ), $P_{H O i}$ is ordinate points (load, H). Values $R_{b}(t)$ and $R_{b t}$ (t) are determined according to equations proposed in [7].

Given these, coordinates the points of tensile " $\sigma-\varepsilon$ " diagrams for SFRSC will be determined by the following formulas:

Table 3

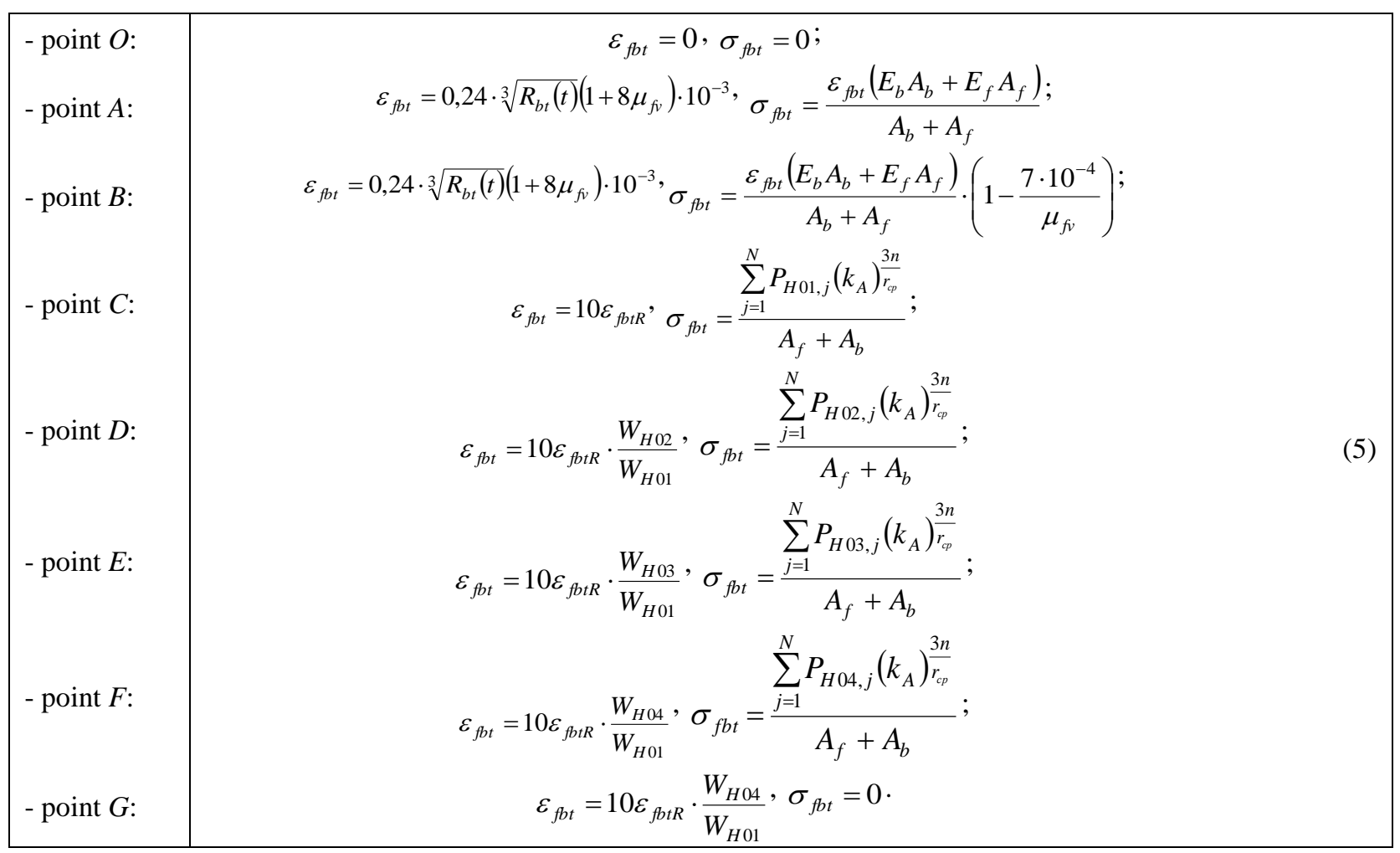

Where $N$ is quantity of fibers in SFRSC spacimen, the $n$ - number of fiber within a radius of $10 \mathrm{~mm}$ and affect the operation of the unit central fiber, $r_{c p}$ is the average distance to the fibers located within a radius of $10 \mathrm{~mm}$, the $\mathrm{k}_{\mathrm{A}}$ is coefficient taking into account the work of the central fiber as a result of effect on neighboring fibers, and it is determined by the formula [8]:

$$
k_{A}=\left[\left(0,24 \cdot l_{f, a n}-2,7\right) \cdot \frac{\lambda_{f}^{2}}{R_{m}}+\left(7,7-0,52 \cdot l_{f, a n}\right) \cdot \frac{\lambda_{f}}{R_{m}}+1\right], \lambda_{f}=l_{f, a n, c} / l_{f, a n}
$$




\begin{tabular}{l|lr|ll|ll} 
& ISRA (India) & $=\mathbf{1 . 3 4 4}$ & SIS (USA) & $=\mathbf{0 . 9 1 2}$ & ICV (Poland) & $\mathbf{= 6 . 6 3 0}$ \\
Impact Factor: & ISI (Dubai, UAE) $=\mathbf{0 . 8 2 9}$ & PUHL (Russia) $=\mathbf{0 . 2 3 4}$ & PIF (India) & $=\mathbf{1 . 9 4 0}$ \\
& GIF (Australia) & $=\mathbf{0 . 5 6 4}$ & ESJI (KZ) & $=\mathbf{1 . 0 4 2}$ & IBI (India) & $=\mathbf{4 . 2 6 0}$
\end{tabular}

where, $l_{f, a n, c}$ is the mean value of the anchorage of neighboring fibers, $\mathrm{mm}$.

Note that for each fiber, which diagramm summarize, it is necessary to calculate the parameters: $n, r_{c p}$ and $k_{A}$.

Such representation of " $\sigma-\varepsilon "$ diagrams for SFRSC specimens tensile, requires consideration of

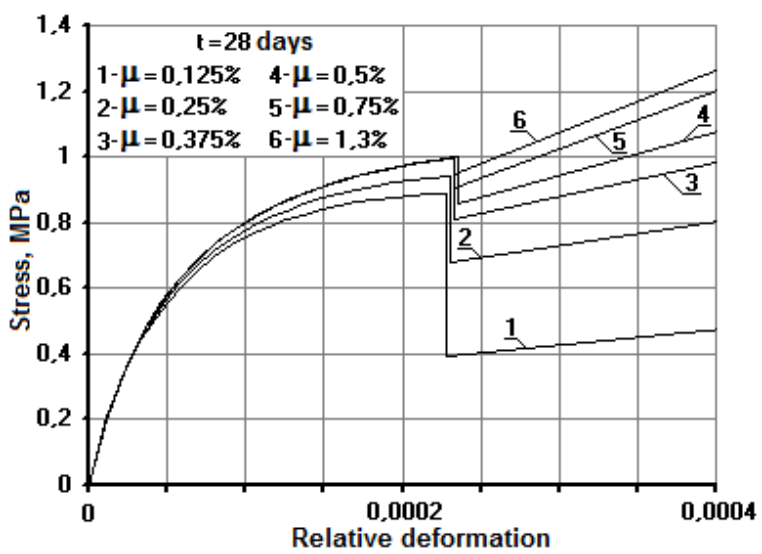

the large amount of data, it is convenient to use in the calculation of structural elements on a computer.

Figures 6 illustrate the theoretical curves constructed by the formulas (3)-(6) for concrete class B20 and at matrix age 28 days.

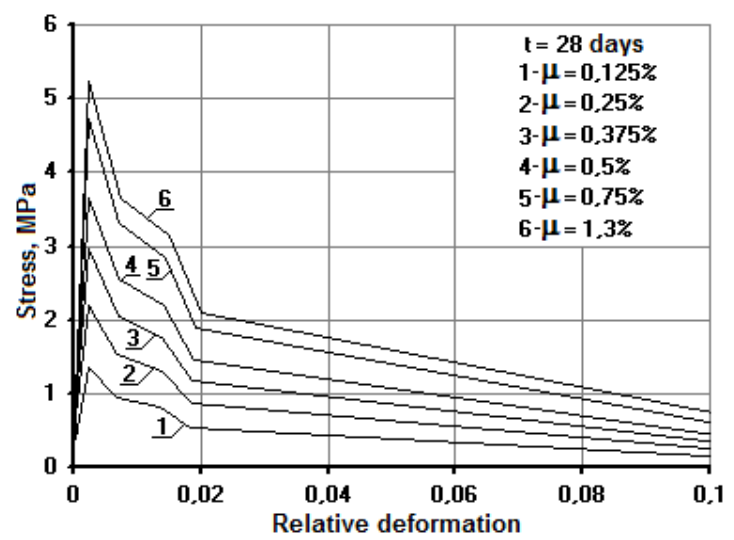

Figure 6 - Theoretical " $\sigma-\varepsilon$ " diagrams for tensile SFRC constructed according to formulas (5), (6)

The test results of the SFRSC specimens under axial compression are shown in Fig. 7 a (slag concrete B7.5 class at the age of 3 days, $k_{n}=1$ ), and

a)

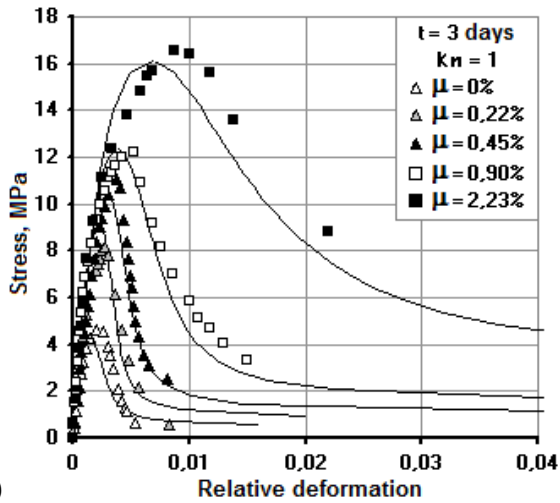

in Fig. 7 b (slag concrete class B15 at the age of 3 days, $\left.k_{n}=0,247\right)$.

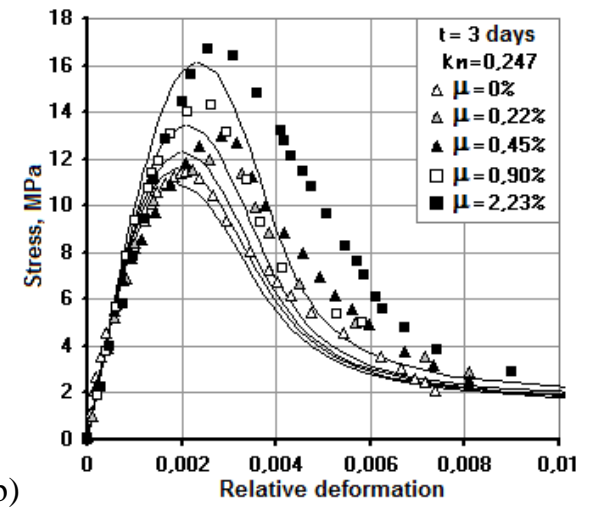

Figure 7 - The experimental data and the theoretical curves " $\sigma-\varepsilon$ ", obtained when tested on specimens in axial compression SFRSC

One of the known analytical expressions, allowing to express the relation between stress and strain of concrete under axial compression is the

$$
v_{(f) b}=v_{(f) b, R} \pm\left(v_{0}-v_{(f) b, R}\right) \sqrt{1-\omega_{1} \eta-\omega_{2} \eta^{2}},
$$

where $v_{(f f b, R}$ is the rate of change secant modulus $v_{(f f b}$ $\left(0<v_{(f) b}<1\right)$ in the top of the " $\sigma-\varepsilon "$ diagram:

$$
v_{(f) b, R}=\sigma_{(f) b, R} /\left(\varepsilon_{(f) b, R} E_{(f) b}\right), \sigma_{(f) b, R}=R_{(f) b},
$$

$v_{(f) b, R}$ is relative strain at the maximum stress, $E_{(f) b t}$ is initial modulus of elasticity of concrete in tension, $\eta$ $(0<\eta<1)$ is stress level:
ISPC Theory and Practice,

Lancaster, USA 


\begin{tabular}{|c|c|c|c|c|c|c|}
\hline Impact Factor: & $\begin{array}{l}\text { ISRA (India) } \\
\text { ISI (Dubai, UAE } \\
\text { GIF (Australia) } \\
\text { JIF }\end{array}$ & $\begin{array}{l}=1.344 \\
=0.829 \\
=0.564 \\
=1.500\end{array}$ & $\begin{array}{l}\text { SIS (USA) } \\
\text { PИНЦ (Russia) } \\
\text { ESJI (KZ) } \\
\text { SJIF (Morocco) }\end{array}$ & $\begin{array}{l}=0.912 \\
=0.234 \\
=1.042 \\
=2.031\end{array}$ & $\begin{array}{l}\text { ICV (Poland) } \\
\text { PIF (India) } \\
\text { IBI (India) }\end{array}$ & $\begin{array}{l}=6.630 \\
=1.940 \\
=4.260\end{array}$ \\
\hline
\end{tabular}

$$
\eta=\sigma_{(f) b} / \sigma_{(f) b, R},
$$

$v_{0}$ is rate of change secant modulus at the beginning of the diagram $\left(v_{0}=1\right.$ for the diagram uplink and $v_{0}=2.05 v_{(f) b, R}$ for downlink diagram), $\omega_{1}, \omega_{2}$ is the parameters of the diagram curvature.

$$
E_{(f) b}^{\prime}=\frac{\sigma_{(f) b}}{\varepsilon_{(f) b}}=v_{(f) b} E_{(f) b}^{0},
$$

In [9] suggested parameters of diagram - for the uplink diagram: curvature determined by the next formulas.

- for downlink diagram:

$$
\omega_{1}=2-2,5 v_{(f) b, R}, \omega_{2}=1-\omega_{1} ;
$$

$$
\omega_{1}=1,95 v_{(f) b, R}-0,138, \omega_{2}=1-\omega_{1} .
$$

To describe the stress-strain state of concrete applied modified depending offered N. I. Karpenko and C. Sujivorakul. The mathematical models used piecewise linear displacement diagrams fibers in concrete. The coordinates for these diagrams were obtained by analyzing the experimental data. The theoretical curves constructed using formulas showed high agreement with experimental data.

\section{References:}

1. Korneev M, Buzina OP, Sukhanov AV, Shipulin IA, Shipulin NA (2013) "The study of the mechanical properties of fine-grained cinder concrete under axial tension and compression," International Scientific Journal Theoretical \& Applied Science, vol. 30, pp. 65-71, Oct 2015.

2. (2013) Patent RF №2544299, 2013.

3. Edgington J, Hannant DJ, Williams RIT (1982) "Steel wire reinforced concrete," Fiber reinforced materials, Moscow, 1982, pp.135150.

4. (2012) Sujivorakul, "Model of hooked steel fibers reinforced concrete under tension," High performance fiber reinforced cement composites 6, Springer Dordrecht Heidelberg London New York, RILEM, 2012, pp. 559.

5. Shah SP, Rangan BV (1971) "Fiber reinforced concrete properties," ACI Journal, vol. 68, pp. 126-134, 1971

6. Chernousov NN, Chernousov RN, Sukhanov AV (2015) "Study fixings steel fibers in finegraned slag concrete," Bulletin of the Tomsk
State Architectural University, vol. 5, pp. 117126, May 2015.

7. Chernousov NN, Chernousov RN, Sukhanov AV (2015) "Influence of age fine-grained cinder concrete at its strength characteristics," Scientific Bulletin of Voronezh State Architecture and Construction University. Construction and architecture, vol. 1(37), pp. 41-50, Jan, 2015.

8. Korneev M, Buzina OP, Sukhanov AV, Shipulin IA (2016) "Mathematical modeling of process mutual influence of steel fibers in the cross section in the bending steel fiber reinforced slag concrete element," Fundamental research, vol. 3, pp. 506-511, Apr 2016.

9. Karpenko NI, Radaykin OV (2012) "To improve the concrete stress-strain diagram for determining the moment of cracking and damaging moment in flexural concrete elements," Construction and reconstruction, vol. 3, pp. 10-16, Mar 2012. 